\title{
Pengaruh Independensi, Keahlian Profesional, dan Pengalaman Kerja pada Kinerja Pengawas Koperasi Serba Usaha
}

\author{
Komang Rurkiyasa Adi Putra ${ }^{1}$ \\ Fakultas Ekonomi dan Bisnis \\ Universitas Udayana, Indonesia
}

\author{
I Wayan Pradnyantha Wirasedana ${ }^{2}$ \\ Fakultas Ekonomi dan Bisnis \\ Universitas Udayana, Indonesia
}

\begin{abstract}
Surel : rurkiyasa@gmail.com
ABSTRAK

Tujuan penelitian ini adalah untuk mengetahui pengaruh independensi, keahlian profesional, dan pengalaman kerja pada kinerja pengawas Koperasi Serba Usaha di Kelurahan Kesiman. populasinya di Kelurahan Kesiman berjumlah sebanyak 105 orang. Teknik analisis yang digunakan dalam penelitian ini adalah analisis regresi linear berganda. Hasil dari penelitian ini menunjukkan bahwa independensi, keahlian profesional, pengalaman kerja berpengaruh positif dan signifikan pada kinerja pengawas Koperasi Serba Usaha di Kecamaran Denpasar Timur. Adjusted $R^{2}$ adalah 0,831 . Hal ini menunjukkan bahwa $83,1 \%$ variasi kinerja pengawas dapat dijelaskan oleh variabel independensi, keahlian profesional, dan pengalaman kerja, sedangkan sisanya sebesar 16,9\% dijelaskan oleh variabel lain di luar model.
\end{abstract}

Kata Kunci: Independensi, Keahlian Profesional; Pengalaman Kerja; Pengawai; Kinerja.

\section{Influence of Independence, Professional Expertise, and Work Experience on the Performance of Koperasi Serba Usaha}

\footnotetext{
ABSTRACT

The purpose of this study was to determine the effect of independence, professional expertise, and work experience on the performance of Koperasi Serba Usaha. The analysis technique used in this study is multiple linear regression analysis. The results of this study indicate that independence, professional expertise, work experience have a positive and significant effect on the performance of Multipurpose Cooperative supervisors in East Denpasar Sub-District. Adjusted R2 is 0.831 . This shows that $83.1 \%$ of the variation in supervisor performance can be explained by the variables of independence, professional expertise, and work experience, while the remaining $16.9 \%$ is explained by other variables outside the model.
}

Keywords: Independence, Professional Expertise; Work Experience; Employee; The Performance.

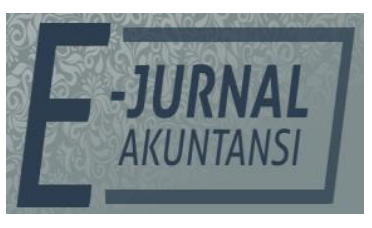

e-ISSN 2302-8556

Vol. 30 No. 10

Denpasar, Oktober 2020

Hal. 2540-2550

DOI:

10.24843/EJA.2020.v30.i10.p08

PENGUTIPAN:

Putra, K. R. A. \&

Wirasedana, I P. W. (2020).

Pengaruh Independensi,

Keahlian Profesional, dan

Pengalaman Kerja pada

Kinerja Pengawas Koperasi Serba Usaha. E-Jurnal Akuntansi, 30(10), 2540-2550

RIWAYAT ARTIKEL:

Artikel Masuk:

15 Januari 2020

Artikel Diterima: 29 Juli 2020

Artikel dapat diakses : https://ojs.unud.ac.id/index.php/Akuntansi/index 


\section{PENDAHULUAN}

Pentingnya eksistensi seorang pengawas menuntut mereka untuk memiliki sikap independensi, keahlian profesional dan pengalaman kerja dalam melaksanakan tugas pemeriksaannya untuk menghindari terjadinya penyimpangan. Independensi seorang pengawas adalah integritas diri pengawas dalam mempertimbangkan fakta dan adanya pertimbangan yang objektif serta tidak memihak dalam merumuskan dan menyatakan pendapat. Integritas merupakan sikap moral yang tidak memihak, jujur, memandang dan mengemukakan fakta apa adanya. Independensi juga berarti adanya kejujuran dalam diri auditor dalam mempertimbangkan fakta dan adanya pertimbangan yang objektif tidak memihak dalam diri auditor dalam merumuskan dan menyatakan pendapatnya. Auditor harus bersikap independen karena auditor bekerja demi kepentingan umum. Dengan demikian independensi merupakan standar kualitatif yang diperlukan oleh akuntan publik untuk bertindak dengan integritas dan obyektivitas dalam melaksanakan tugas profesionalnya (Dianawati \& Ramantha, 2013). Berdasarkan penelitian yang dilakukan (Septriani, 2012) dan (Bawono \& Singgih, 2016), independensi berpengaruh signifikan positif terhadap kinerja auditor. Dalam penelitian yang dilakukan oleh (Badjuri \& Kunci, 2011) diperoleh hasil bahwa independensi berpengaruh positif terhadap kinerja auditor. Oleh karena itu hipotesis dalam penelitian ini adalah Independensi berpengaruh positif pada kinerja pengawas.

Keahlian profesional mencakup pengetahuan tentang suatu lingkungan, pemahaman dan keterampilan. Untuk memiliki keahlian profesional, seorang pengawas harus didukung dengan adanya latar belakang pendidikan di bidang auditing, akuntansi, dan perbankan. Selain itu diperlukan juga training yang cukup terutama terkait pengetahuan auditing dan akuntansi. Auditor harus senantiasa bertindak sebagai seorang ahli dalam bidang akuntansi dan bidang auditing, pencapaian keahlian tersebut dimulai dari pendidikan formal yang kemudian diperluas melalui pengalaman dan dalam praktik audit, serta seorang auditor harus menjalani pelatihan teknis yang cukup, pelatihan ini harus secara memadai mencakup aspek teknis maupun pendidikan formal (Romadhina, 2016). Berdasarkan penelitianmyang dilakukan (Saputra \& Yasa, 2013) dan (Wicaksana \& Budiartha, 2015) diperoleh hasil keahlian profesional berpengaruh positif dan signifikan pada kinerja auditor. Oleh karena itu hipotesis dalam penelitian ini adalah keahlian profesional berpengaruh positif pada kinerja pengawas.

Pengalaman kerja juga merupakan faktor penting dalam memprediksi dan menilai kinerja pengawas dalam melakukan pengawasan. Pengalaman kerja akan menambah atau memberikan keahlian profesional bagi pengawas. Pengalaman kerja yang dimiliki juga akan menambah daya tanggap dan ketelitian seseorang. Menurut penelitian tentang pengalaman kerja yang dilakukan oleh (Dianawati \& Ramantha, 2013) bahwa Pengalaman kerja merupakan suatu proses pembelajaran dan pertambahan potensi bertingkah laku baik dari pendidikan formal maupun non formal atau bisa diartikan sebagai suatu proses yang membawa seseorang kepada suatu pola tingkah yang lebih tinggi. Variabel pengalaman akan diukur dengan menggunakan indikator lamanya bekerja, frekuensi pekerjaan pemeriksaan yang telah dilakukan, dan banyaknya pelatihan yang telah diikutinya. Apabila Pengawas telah menerapkan prinsip independensi, keahlian 
profesional, dan pengalaman kerja dalam melaksanakan pemeriksaannya terhadap seluruh aktivitas koperasi serba usaha maka kualitas laporan yang dihasilkan akan semakin baik. Laporan yang berkualitas dapat dijadikan acuan bagi manajemen dalam mengambil keputusan yang tepat untuk menindaklanjuti laporan tersebut. Penelitian yang dilakukan oleh (Dianawati \& Ramantha, 2013) tentang pengaruh independensi, keahlian profesional dan pengalaman kerja auditor internal terhadap efektivitas struktur pengendalian internal bank perkreditan rakyat di kabupaten Gianyar menunjukkan bahwa pengalaman kerja berpengaruh positif terhadap penerapan efektivitas struktur pengendalian intern BPR di Kabupaten Gianyar. Penelitian ini juga didukung oleh penelitian (Larkin, 2004) dan (Glover et al., 2002). (Larkin, 2004) melakukan penelitian yang melibatkan internal auditor di lembaga keuangan dan menyatakan bahwa internal auditor berpengalaman cenderung lebih konservatif dalam menghadapi situasi dilemma etika. Oleh karena itu hipotesis dalam penelitian ini adalah pengalaman kerja berpengaruh positif pada kinerja pengawas.

Bali khususnya Denpasar merupakan daerah koperasi yang berhasil di Indonesia. Hanya saja, reputasi itu belum diikuti dengan manajemen koperasi yang baik. Kemampuan pengelolaan koperasi di Bali perlu ditingkatkan bersamaan dengan peningkatan kinerja pengawas. Independensi pengawas koperasi merupakan salah satu faktor penting. Hal tersebut mendorong peneliti untuk meneliti kembali variabel independensi terhadap kinerja pengawas.

Tujuan utama dari koperasi adalah meningkatkan kesejahteraan anggota koperasi. Sama halnya dengan Koperasi Serba Usaha yang tujuan utamanya juga mensejahterakan anggotanya. Untuk dapat mencapai tujuan tersebut, selain menjalankan aktivitas kegiatan koperasi secara efektif dan efisien koperasi juga mencari keuntungan yang diistilahkan dengan Sisa Hasil Usaha (SHU) agar mampu mensejahterakan anggotanya. Jadi pada akhir periode semua anggota koperasi memperoleh SHU. Hal ini sekaligus juga menandakan bahwa koperasi tersebut adalah koperasi yang aktif dan diharapkan dapat berkembang nantinya.

Fenomena yang mencerminkan bahwa terkadang pengawas koperasi tidak profesional seperti dugaan penggelapan uang tabungan anggota oleh ketua KSU sejumlah ratusan juta rupiah. Ini terjadi dikarenakan pengurus koperasi yang lama banyak berkelit dengan berbagai alasan saat anggotanya hendak menarik tabungannya. Dari keterangan pengurus baru bahwa sejumlah uang itu dipakai oleh pengurus yang lama. Dimana berdasarkan RAT tahun 2016 terlihat bahwa rentang selisih laporan terbilang besar, misalnya transport dana yang terpakai dari tahun ke tahun terlihat jelas perbedaannya sangat besar (baliexpress.jawapos.com)

Perkembangan jumlah koperasi di Kecamatan Denpasar Timur meningkat dari tahun ke tahun. Di Kecamatan Denpasar Timur koperasi serba usaha tersebar di empat kelurahan. Tabel 1, menyajikan data perkembangan jumlah koperasi serba usaha dari tahun 2015 sampai tahun 2019.

Berdasarkan Tabel 1, dapat dilihat pada tahun 2019 di Denpasar Timur terdapat 92 unit Koperasi Serba Usaha yang tersebar di empat keclurahan yaitu Kelurahan Kesiman, Kelurahan Dangin Puri, Kelurahan Sumerta serta Kelurahan Penatih. Pada tahun 2019 terlihat bahwa Kelurahan Kesiman memiliki jumlah Koperasi Serba Usaha tertinggi. Hal ini mengindikasikan bahwa animo 
masyarakat akan lembaga keuangan mikro di Kelurahan Kesiman lebih tinggi jika dibandingkan dengan ketiga kelurahan lainnya.

Tabel 1. Perkembangan Jumlah Koperasi Serba Usaha Di Kecamatan Denpasar Timur Tahun 2015-2019

\begin{tabular}{llllll}
\hline Kelurahan & 2015 & 2016 & 2017 & 2018 & 2019 \\
\hline Kesiman & 19 & 22 & 25 & 29 & 35 \\
Dangin Puri & 8 & 10 & 13 & 15 & 17 \\
Sumerta & 9 & 13 & 17 & 16 & 18 \\
Penatih & 11 & 13 & 16 & 20 & 22 \\
Total & 47 & 58 & 71 & 80 & 92
\end{tabular}

Sumber: Dinas Koperasi dan UKM Kota Denpasar, 2019

Menurut (Hery, 2010) Independensi merupakan sikap mandiri dan terpisah dari berbagai kegiatan yang diperiksa. Setiap pengawas harus memelihara integritas dan objektivitas dalam tugas profesionalnya. Independensi berpengaruh positif terhadap kinerja pengawas. (Hirth Jr., 2008) dalam penelitiannya menunjukkan bahwa seorang auditor internal yang baik harus memiliki sikap independensi. Sikap independensi dirasa sangat penting dalam melaksanakan pengawasan yang efektif. Penelitian (Putri \& Suputra, 2013) membuktikan bahwa independensi berpengaruh positif terhadap kinerja auditor. (Allen et al., 2005) menyatakan hal yang sama bahwa independensi berpengaruh positif terhadap kinerja auditor, yang dapat disimpulkan bahwa semakin tinggi independensi maka kinerja auditor yang dihasilkan semakin baik. Hal ini juga diperkuat dengan penelitian yang dilakukan oleh (Gustia, 2014) membuktikan bahwa independensi berpengaruh pada kinerja auditor.

$\mathrm{H}_{1}$ : Independensi berpengaruh positif pada kinerja pengawas Koperasi Serba Usaha di Kelurahan Kesiman.

Keahlian profesional berpengaruh positif pada kinerja. Hal ini terungkap dalam penelitian yang dilakukan oleh (Dianawati \& Ramantha, 2013) yang berjudul "Pengaruh Independensi, Keahlian Profesional, dan Pengalaman Kerja Badan Pengawas terhadap Efektivitas Struktur Pengendalian Intern pada Bank Perkreditan Rakyat di Kabupaten Gianyar". Hasil penelitian ini membuktikan bahwa keahlian profesional yang dimiliki oleh badan pengawas berpengaruh positif dan signifikan terhadap kinerja badan pengawas sebagai fungsi auditor internal dalam pengawasan kredit. Hal ini mengarah pada efektivitas dan kinerja badan pengawas yang nantinya akan berpengaruh pada efektivitas struktur pengendalian intern.

$\mathrm{H}_{2}$ : Keahlian profesional berpengaruh positif pada kinerja pengawas Koperasi Serba Usaha di Kelurahan Kesiman.

(Larkin, 2004) melakukan penelitian yang melibatkan internal auditor di lembaga keuangandan menyatakan bahwa internal auditor berpengalaman cenderung lebih konservatif dalam menghadapi situasi dilemma etika. (Glover et al., 2002) melakukan penelitian pada beberapa mahasiswa program bisnis dan menyatakan bahwa mahasiswa senior telah berperilaku etis dibandingkan dengan yang lebih junior.

Pengalaman kerja berpengaruh positif pada kinerja. Hal ini terungkap dalam penelitian yang dilakukan oleh (Dianawati \& Ramantha, 2013) tentang pengaruh independensi, keahlian profesional dan pengalaman kerja auditor 
internal terhadap efektivitas struktur pengendalian internal bank perkreditan rakyat di kabupaten Gianyar.

$\mathrm{H}_{3}$ : Pengalaman kerja berpengaruh positif pada kinerja pengawas Koperasi Serba Usaha di Kelurahan Kesiman.

\section{METODE PENELITIAN}

Penelitian ini dilakukan pada koperasi serba usaha yang ada di Kelurahan Kesiman. Dipilihnya koperasi serba usaha sebagai lokasi penelitian karena pertumbuhan jumlah koperasi serba usaha di Kelurahan Kesiman cukup tinggi dari tahun ke tahun. Pertumbuhan jumlah koperasi yang cukup tinggi di Kelurahan Kesiman ini sebaiknya dibarengi dengan kinerja auditor internal yang optimal sehingga tujuan dari manajemen dapat tercapai dengan baik. Selain itu koperasi serba usaha juga memiliki pengendalian intern seperti entitas bisnis lainnya dan memiliki pengawasan intern yang berfungsi sebagai pengawas.

Populasi dalam penelitian ini adalah pengawas koperasi serba usaha yang ada di Kelurahan Kesiman. Adapun populasi tersebut dalam penelitian ini berjumlah 105 untuk itu jumlah sampel disesuaikan dengan pedoman dari Roscoe (1982) tentang ukuran sampel untuk penelitian yang menggunakan teknik analisis regresi berganda adalah minimal 10 kali dari jumlah variabel yang diteliti. Sehingga jumlah sampel yang digunakan yaitu $10 \times 4=40$.

Analisis regresi linier berganda dipergunakan untuk mengetahui ketergantungan satu variabel terikat hanya pada satu variabel bebas dengan atau tanpa variabel moderator, serta untuk mengetahui ketergantungan satu variabel terikat pada variabel-variabel bebas. Teknik analisis ini digunakan untuk mengetahui pengaruh independensi, keahlian professional, dan pengalaman kerja pada kinerja pengawas koperasi serba usaha di kelurahan kesiman. Hasil analisis dinyatakan dalam bentuk persamaan regresi linier berganda sebagai berikut .

$$
Y=\alpha+\beta_{1} X_{1}+\beta_{2} X_{2}+\beta_{3} X_{3}+\varepsilon
$$

Keterangan:

$$
\begin{array}{ll}
Y & : \text { kinerja pengawas } \\
\alpha & : \text { konstanta } \\
X_{1} & : \text { independensi } \\
X_{2} & : \text { keahlian profesional } \\
X_{3} & : \text { pengalaman kerja } \\
\beta_{1} & : \text { koefisien regresi variabel independensi } \\
\beta_{2} & : \text { koefisien regresi variabel keahlian profesional } \\
\beta_{3} & : \text { koefisien regresi variabel pengalaman kerja } \\
\varepsilon & : \text { standard error / variabel pengganggu }
\end{array}
$$

\section{HASIL DAN PEMBAHASAN}

Statistik Deskriptif digunakan untuk memberikan gambaran atau deskriptif suatu data yang dilihat dari nilai rata-rata (mean), nilai minimum, nilai maksimum, dan nilai dari data penelitian. Hasil dari pengujian statistik deskriptif dari masingmasing variabel penelitian disajikan pada Tabel 2. Nilai rata-rata variabel independensi Koperasi Serba Usaha Di Kelurahan Kesiman sebesar 3,1757. Nilai minimum dan maksimum independensi Koperasi Serba Usaha Di Kelurahan Kesiman paling rendah sebesar 1,56 dan paling tinggi sebesar 4,00. Nilai rata-rata 
variabel keahlian profesional Koperasi Serba Usaha Di Kelurahan Kesiman sebesar 3,2605.

Tabel 2. Hasil Uji Statistik Deskriptif

\begin{tabular}{llllll}
\hline Variabel & $\mathrm{N}$ & Minimum & Maximum & Mean & Std. Deviation \\
\hline Independensi & 40 & 1.56 & 4.00 & 3.1757 & 0.73625 \\
Keahlian Profesional & 40 & 1.29 & 4.00 & 3.2605 & 0.91143 \\
Pengalaman Kerja & 40 & 1.17 & 4.00 & 3.3503 & 0.77347 \\
Kinerja Pengawas & 40 & 1.46 & 4.00 & 3.2925 & 0.74713 \\
\hline
\end{tabular}

Sumber: Data Penelitian, 2019

Nilai minimum dan maksimum keahlian profesional Koperasi Serba Usaha Di Kelurahan Kesiman paling rendah sebesar 1,29 dan paling tinggi sebesar 4,00. Nilai rata-rata variabel pengalaman kerja di Koperasi Serba Usaha Di Kelurahan Kesiman sebesar 3,3503. Nilai minimum dan maksimum pengalaman kerja di Koperasi Serba Usaha Di Kelurahan Kesiman paling rendah sebesar 1,17 dan paling tinggi sebesar 4,00. Nilai rata-rata variabel kinerja pengawas Koperasi Serba Usaha Di Kelurahan Kesiman sebesar 3,2925. Nilai minimum dan maksimum kinerja pengawas Koperasi Serba Usaha Di Kelurahan Kesiman paling rendah sebesar 1,46 dan paling tinggi sebesar 4,00.

Hasil analisis ini mengacu pada hasil pengaruh variabel Independensi $\left(\mathrm{X}_{1}\right)$, variabel Keahlian profesional $\left(X_{2}\right)$ variabel Pengalaman kerja $\left(X_{3}\right)$ terhadap Kinerja pengawas (Y) Koperasi Serba Usaha Di Kelurahan Kesiman Adapun hasil analisis regresi dengan program Statitical Pacage of Social Science (SPSS) versi 21.0 for Windows dapat dilihat pada Tabel 3 berikut.

Tabel 3. Rangkuman Hasil Analisis Regresi Linear Berganda

\begin{tabular}{lllllc}
\hline \multirow{2}{*}{ Model } & \multicolumn{2}{l}{$\begin{array}{l}\text { Unstandardized } \\
\text { Coefficients }\end{array}$} & $\begin{array}{l}\text { Standardized } \\
\text { Coefficients }\end{array}$ & $\mathrm{t}$ & \multirow{2}{*}{ Sig. } \\
\cline { 2 - 4 } & $\mathrm{B}$ & Std. Error & Beta & \\
\hline (Constant) & 0.000 & 0.065 & & 0.000 & 1.000 \\
Independensi & 0.364 & 0.100 & 0.364 & 3.648 & 0.001 \\
Keahlian profesional & 0.316 & 0.093 & 0.316 & 3.404 & 0.002 \\
Pengalaman kerja & 0.355 & 0.106 & 0.355 & 3.343 & 0.002 \\
\hline
\end{tabular}

Sumber: Data Penelitian, 2019

Berdasarkan Tabel 3, dapat ditulis persamaan regresi linear berganda sebagai berikut.

$$
Y=-0,008+0,364 X_{1}+0,316 X_{2}+0,355 X_{3}
$$

Dimana :

$\mathrm{Y}=$ Kinerja pengawas

$\mathrm{X}_{1}=$ Independensi

$\mathrm{X}_{2}=$ Keahlian profesional

$\mathrm{X}_{3}=$ Pengalaman kerja

Berdasarkan pengolahan data SPSS dihasilkan tingkat signifikansi 0,001 < 0,05. Berdasarkan nilai pengujian tersebut, dapat dilihat dengan statistik bahwa uji jatuh pada penolakan $\mathrm{H}_{0}$ ditolak dan $\mathrm{H}_{1}$ diterima untuk hipotesis pertama. Hal tersebut menyatakan penerimaan hipotesis yang bahwa terdapat pengaruh positif dan signifikan antara Independensi terhadap Kinerja pengawas Koperasi Serba Usaha Di Kelurahan Kesiman. Koefisien variabel X1 adalah positif 0,364 artinya 
Independensi berpengaruh positif terhadap Kinerja pengawas. Apabila Independensi meningkat sedangkan Keahlian profesional dan Pengalaman kerja tetap, maka Kinerja pengawas akan meningkat sebesar 0,364. Hasil penelitian ini sesuai dengan penelitian yang dilakukan oleh (Hirth Jr., 2008) dalam penelitiannya menunjukkan bahwa seorang auditor internal yang baik harus memiliki sikap independensi. Sikap independensi dirasa sangat penting dalam melaksanakan pengawasan yang efektif. Penelitian (Putri \& Suputra, 2013) membuktikan bahwa independensi berpengaruh positif terhadap kinerja auditor. (Allen et al., 2005) menyatakan hal yang sama bahwa independensi berpengaruh positif terhadap kinerja auditor, yang dapat disimpulkan bahwa semakin tinggi independensi maka kinerja auditor yang dihasilkan semakin baik. Hal ini juga diperkuat dengan penelitian yang dilakukan oleh (Gustia, 2014) membuktikan bahwa independensi berpengaruh pada kinerja auditor.

Berdasarkan pengolahan data SPSS dihasilkan tingkat signifikansi 0,002< 0,05 . Berdasarkan nilai pengujian tersebut, dapat dilihat dengan statistik bahwa uji jatuh pada penolakan $\mathrm{H}_{0}$ ditolak dan $\mathrm{H}_{1}$ diterima untuk hipotesis kedua. Hal tersebut menyatakan penerimaan hipotesis yang bahwa terdapat pengaruh positif dan signifikan antara terhadap Kinerja pengawas Koperasi Serba Usaha Di Kelurahan Kesiman .Koefisien variabel X2 adalah positif 0,316, artinya Keahlian profesional berpengaruh positif terhadap Kinerja pengawas. Apabila Keahlian profesional meningkat sedangkan Independensi dan Pengalaman kerja tetap, maka Kinerja pengawas akan meningkat sebesar 0,316. Hasil penelitian ini sesuai dengan penelitian yang dilakukan oleh (Dianawati \& Ramantha, 2013) yang berjudul "Pengaruh Independensi, Keahlian Profesional, dan Pengalaman Kerja Badan Pengawas terhadap Efektivitas Struktur Pengendalian Intern pada Bank Perkreditan Rakyat di Kabupaten Gianyar". Hasil penelitian ini membuktikan bahwa keahlian profesional yang dimiliki oleh badan pengawas berpengaruh positif dan signifikan terhadap kinerja badan pengawas sebagai fungsi auditor internal dalam pengawasan kredit. Hal ini mengarah pada efektivitas dan kinerja badan pengawas yang nantinya akan berpengaruh pada efektivitas struktur pengendalian intern.

Berdasarkan pengolahan data SPSS dihasilkan tingkat signifikansi 0,002 < 0,05. Berdasarkan nilai pengujian tersebut, dapat dilihat dengan statistik bahwa uji jatuh pada penolakan $\mathrm{H}_{0}$ ditolak dan $\mathrm{H}_{1}$ diterima untuk hipotesis kedua. Hal tersebut menyatakan penerimaan hipotesis yang bahwa terdapat pengaruh positif dan signifikan antara terhadap Kinerja pengawas Koperasi Serba Usaha Di Kelurahan Kesiman Koefisien variabel X3 adalah positif 0,355, artinya Pengalaman kerja berpengaruh positif terhadap Kinerja pengawas. Apabila Pengalaman kerja meningkat sedangkan Independensi dan Keahlian profesional tetap, maka Kinerja pengawas akan meningkat sebesar 0,355. Hasil penelitian ini sesuai dengan penelitian yang dilakukan oleh (Larkin, 2004) melakukan penelitian yang melibatkan internal auditor di lembaga keuangan dan menyatakan bahwa internal auditor berpengalaman cenderung lebih konservatif dalam menghadapi situasi dilemma etika. (Glover et al., 2002) melakukan penelitian pada beberapa mahasiswa program bisnis dan menyatakan bahwa mahasiswa senior telah berperilaku etis dibandingkan dengan yang lebih junior. Pengalaman kerja berpengaruh positif pada kinerja. Hal ini terungkap dalam penelitian yang 
dilakukan oleh (Dianawati \& Ramantha, 2013) tentang pengaruh independensi, keahlian profesional dan pengalaman kerja auditor internal terhadap efektivitas struktur pengendalian internal bank perkreditan rakyat di kabupaten Gianyar.

Analisis derteminasi dilakukan untuk mengetahui sejauh mana variasi variabel bebas yaitu X1 (Independensi), X2 (Keahlian profesional ) dan X3 (Pengalaman kerja) terhadap variabel Kinerja pengawas (Y). berdasarkan hasil spss yang dapat dilihat pada Tabel 4.

Tabel 4. Analisis Determinasi

\begin{tabular}{llllll}
\hline Model & $\mathrm{R}$ & $\mathrm{R}$ Square & Adjusted R Square & $\begin{array}{l}\text { Std. Error of the } \\
\text { Estimate }\end{array}$ \\
\hline 1 & $0.919 \mathrm{a}$ & 0.844 & 0.831 & 0.41080948 & \\
\hline
\end{tabular}

Sumber: Data Penelitian, 2019

Berdasarkan Tabel 4, tersebut dapat diketahui bahwa nilai $\mathrm{r}$ square $\left(\mathbf{r}^{2}\right)=$ 0,844 Adapun analisis menggunakan rumus sebagai berikut.

$$
\begin{aligned}
& D=\mathbf{r}^{2} \times 100 \% \\
& D=0,844 \times 100 \% \\
& D=84,4 \%
\end{aligned}
$$

Berdasarkan hasil tersebut diketahui bahwa nilai $\mathrm{R}^{2}=84,4$ persen, yang berarti bahwa sebesar 84,4 persen Kinerja pengawas Koperasi Serba Usaha Di Kelurahan Kesiman dipengaruhi oleh variabel Independensi (X1) ,Keahlian profesional (X2), dan Pengalaman kerja (X3) dan sisanya sebesar 15,6 persen dipengaruhi oleh variabel lain yang tidak diteliti pada penelitian ini.

Uji F digunakan untuk mengetahui apakah secara serempak (simultan) seluruh variabel bebas (variabel Independensi, variabel Keahlian profesional variabel Pengalaman kerja ) memiliki pengaruh terhadap variabel terikat (Kinerja pengawas). Tabel 5, menunjukkan hasil perhitungan uji $\mathrm{F}$ dengan menggunakan SPSS 21.

\section{Tabel 5. Hasil Uji F}

\begin{tabular}{lllllll}
\hline Model & & Sum of Squares & Df & Mean Square & F & Sig. \\
\hline \multirow{2}{*}{1} & Regression & 32.924 & 3 & 10.975 & 65.030 & $0.000^{\mathrm{b}}$ \\
& Residual & 6.076 & 36 & 0.169 & & \\
& Total & 39.000 & 39 & & & \\
\hline
\end{tabular}

Sumber: Data Penelitian, 2019

Berdasarkan hasil analisis, diketahui nilai signifikansi $\mathrm{F}$ adalah $0,000<0,05$, maka $\mathrm{H}_{0}$ ditolak. Hal ini berarti bahwa variabel Independensi $\left(X_{1}\right)$, variabel Keahlian profesional $\left(X_{2}\right)$, variabel Pengalaman kerja $\left(X_{3}\right)$, secara simultan berpengaruh signifikan terhadap kinerja pengawas (Y) Koperasi Serba Usaha Di Kelurahan Kesiman, atau model yang digunakan dalam penelitian layak dan dapat dipergunakan untuk analisis berikutnya.

\section{SIMPULAN}

Terdapat pengaruh positif dan signifikan antara Independensi terhadap Kinerja pengawas Koperasi Serba Usaha di Kelurahan Kesiman Hal ini berarti semakin tingginya Independensi, maka akan meningkatkan Kinerja pengawas. Terdapat pengaruh positif dan signifikan antara Keahlian profesional terhadap Kinerja pengawas Koperasi Serba Usaha di Kelurahan Kesiman .Hal ini berarti semakin tingginya Keahlian profesional, maka akan meningkatkan Kinerja pengawas. 
Terdapat pengaruh positif dan signifikan antara Pengalaman kerja terhadap Kinerja pengawas Koperasi Serba Usaha di Kelurahan Kesiman .Hal ini berarti semakin tingginya Pengalaman kerja, maka akan meningkatkan Kinerja pengawas.

Berdasarkan hasil yang diperoleh Independensi, Keahlian profesional dan Pengalaman kerja memiliki pengaruh yang positif signifikan terhadap Kinerja pengawas Koperasi Serba Usaha di Kelurahan Kesiman, ini menunjukan bahwa semakin tinggi Independensi, Keahlian profesional dan Pengalaman kerja Koperasi Serba Usaha di Kelurahan Kesiman. Pihak pengawas Koperasi Serba Usaha di Kelurahan Kesiman harus tetap memertahankan Independensi, Keahlian profesional dan Pengalaman kerja di dalam koperasi agar anggota merasa puas dan dapat berkomitmen terhadap koperasi, sehingga akan meningkatkan Kinerja pengawas Koperasi Serba Usaha di Kelurahan Kesiman. Diharapkan pada peneliti selanjutnya tidak terpaku pada faktor-faktor dalam penelitian ini yaitu Independensi, Keahlian profesional ,dan Pengalaman Kerja, namun dapat menambah faktor-faktor lain yang mungkin memengaruhi Kinerja pengawas.

\section{REFERENSI}

Allen, M. F., Linville, M., \& Stott, D. M. (2005). The Effect of Litigation on Independent Auditor Selection. American Journal of Business. https:// doi.org/10.1108/19355181200500004

Badjuri, A., \& Kunci, K. (2011). Faktor-Faktor Yang Berpengaruh Terhadap Kualitas Audit Auditor Independen Pada Kantor Akuntan Publik (Kap) Di Jawa Tengah Influencing Factors on Independent Auditors Towards Audit Quality in Public Accountant's Offices in Central Java. 3(2), 183-197.

Baliexpress.jawapos.com (2017). Diduga Gelapkan Rp 700 Juta Ketua Ksu Monang Maning Dipolisikan. Retrieved from Baliexpress.jawapos.com website: Baliexpress.jawapos.com/read/2017/11/23/28845/diduga-gelapkan-rp700-juta-ketua-ksu-monang-maning-dipolisikan

Bamber, E. Michael dan Iyer Venkataraman M. (2002). Big 5 auditors' professional and organizational identification: Consistency or conflict. A Journal Practice and Theory Volume, 20(2), 21.

Bonner, S. E., and Sprinkle, G. B. (2002). The effects of monetary incentives on effort and task performance: theories, evidence, and a framework for research. Accountine, Organizations and Society, 27, 303-345.

Bouhawia, M. S., Irianto, G., \& Baridwan, Z. (2015). The Effect of Working Experience, Integrity, Competence, and Organizational Commitment on Audit Quality (Survey State Owned Companies In Libya). IOSR Journal of Economics and Finance Ver. II, 6(4), 2321-5933. https:// doi.org/10.9790/5933-06426067

Bawono, I. R., \& Singgih, E. M. (2016). Faktor-Faktor dalam Diri Auditor dan Kualitas Audit: Studi Pada Kap 'Big Four' di Indonesia. June.

Dianawati, N. M. D., \& Ramantha, W. (2013). Pengaruh Independensi, Keahlian Profesional Dan Pengalaman Kerja Auditor Internal Terhadap Efektivitas Struktur Pengendalian Internal Bank Perkreditan Rakyat Di Kabupaten Gianyar. E-Jurnal Akuntansi, 4(3), 439-450.

Dhiaa, S., \& Thuraiya, A. A. (2017). Factors Influence Internal Audit Effectiveness. 
International Journal of Business and Management. https:// doi.org/10.5539/ijbm.v12n10p143

Glover, S. H., Bumpus, M. A., Sharp, G. F., \& Munchus, G. A. (2002). Gender differences in ethical decision making. Women in Management Review. https:/ / doi.org/10.1108/09649420210433175

Gustia, N. (2014). Pengaruh Independensi Auditor, Etika Profesi, Komitmen Organisasi, Dan Gaya Kepemimpinan Terhadap Kinerja Auditor Pemerintah (Studi Empiris pada Auditor Pemerintah di BPKP Perwakilan Sumbar) ARTIKEL. Jurnal Akutansi, 2(1), 45-48.

Herda, D. N., \& Martin, K. A. (2016). The effects of auditor experience and professional commitment on acceptance of underreporting time: A moderated mediation analysis. Current Issues in Auditing. https:// doi.org/10.2308/ciia-51479

Hery. (2010). Potret Profesi Audit Internal (Di Perusahaan Swasta \& BUMN Terkemuka). Alfabeta.

Hirth Jr., R. B. (2008). Better internal audit leads to better controls. Financial Executive.

Hudiwinarsih, G. (2011). Auditors' Experience, Competency, and Their Independency As the Influencial Factors in Professionalism. Journal of Economics, Business, and Accountancy | Ventura, 13(3), 253-264. https:// doi.org/10.14414/jebav.v13i3.18

Krisnawati, N. P. A., \& Suartana, I. W. (2017). Pengaruh Kompetensi Karyawan, Motivasi Kerja, Komitmen Organisasi, Kemampuan Teknik Personal Terhadap Kinerja Sistem Informasi Akuntansi. E-Jurnal Akuntansi, 21, 25392566. https:/ / doi.org/10.24843/EJA.2017.v20.i03.p30

Larkin, J. M. (2004). The ability of internal auditors to identify ethical dilemmas. In Journal of Business Ethics. https:// doi.org/10.1023/ A:1006150718834

Murtini, N. N., \& Juliarsa, I. G. (2017). Pengaruh Independensi, Keahlian Profesional, Pengalaman Kerja, Dan Tingkat Pendidikan Pada Kinerja Pengawas Koperasi. E-Jurnal Akuntansi, 20, 1390-1418. https:// doi.org/10.24843/EJA.2017.v20.i02.p19

Mukuru, E., \& Kiruja, E. (2013). Effect of Motivation on Employee Performance In Public Middle Level Technical Training Institutions In Kenya. International Journal of Advances in Management and Economics, 16(3), 35-37.

Nur, S. W., \& Fitri. (2017). The Influence of Independence and Competence of Auditor on The Performance of Inspectorate Auditors District MAROS. International Journal of Science and Research (IJSR). https:// doi.org/10.21275/ ART20177179

Prawitasari, P. P., \& Badera, I. D. N. (2015). Pengaruh Independensi, Keahlian Profesional, Dan Pengalaman Kerja Pada Kinerja Pengawas Koperasi Serba Usaha. E-Jurnal Akuntansi, 11(1), 15-28.

Putra, P. B. S., \& Rasmini, N. K. (2014). Pengaruh Independensi, Kompetensi, dan Ruang Lingkup Pekerjaan Audit Pengawas pada Efektivitas Pengendalian Intern Koperasi. E-Jurnal Akuntansi Universitas Udayana.

Putri, K. M. D., \& Suputra, I. D. . D. (2013). Pengaruh Independensi , Profesionalisme, Dan Etika Profesi Terhadap Kinerja Auditor Pada Kantor Akuntan Publik Di Bali. E-Jurnal Akuntansi, 4(1), 39-53. 
Ratna Mappanyuki. (2016). Effects Spiritual Influence Of Auditors , Complexity Task, Ethics Auditor And Auditor Expertise On The Performance Auditor Withaccounting Information Systems With Moderating Variabel ( Empirical Study On Bpkp Representative Office South Sulawesi ). South East Asia Journal of Contemporary Bussines, Economics and Law, 9(1), 28-43.

Romadhina, A. E. F. (2016). Expertise, Independence And Professional Skills Of Internal Auditors In Preventing Fraud On E-Commerce Transactions (A Case Study At Pt Kereta Api Indonesia). Asia Pacific Fraud Journal. https:// doi.org/10.21532/apfj.001.16.01.02.25

Saputra, I. G. W., \& Yasa, G. W. (2013). Pengaruh Independensi, Profesionalisme, Tingkat Pendidikan Dan Pengalaman Kerja Pada Kinerja Auditor Bpk Ri Perwakilan Provinsi Bali. E-Jurnal Akuntansi, 2(2), 488-503.

Septriani, Y. (2012). Auditor Terhadap Kualitas Audit, Studi Kasus Auditor Kap Di Sumatera Barat. Jurnal Akuntansi \& Manajemen, 7(2), 78-100.

Usman. (2015). Effect Of Experience And Accountability On The Quality Of Internal Audit. International Journal of Scientific \& Technology Research, $4(8), 85-90$.

Usman, A., Sudarma, M., Habbe, H., \& Said, D. (2014). Effect of Competence Factor, Independence and Attitude against Professional Auditor Audit Quality Improve Performance in Inspectorate (Inspectorate Empirical Study in South Sulawesi Province). IOSR Journal of Business and Management, 16(1), 01-13. https:// doi.org/10.9790/487x-16120113

Wicaksana, M., \& Budiartha, K. (2015). Tingkat Pendidikan, Pengalaman Kerja, Komitmen Profesional Dan Disiplin Kerja Auditor Pada Rentang Waktu Penyelesaian Audit. E-Jurnal Akuntansi, 13(2), 549-563.

Wulandari, L. R., \& Latrini, M. Y. (2018). Pengaruh Independensi, Pengalaman Kerja, Tingkat Pendidikan dan Pelatihan Kerja Terhadap Efektivitas Struktur Pengendalian Intern LPD. E-Jurnal Akuntansi, 22, 544. https:/ / doi.org/10.24843/EJA.2018.v22.i01.p21

Yahya Andi Sembiring et al, (2014). Influence on the Quality of Experience And Accountability Internal Audit Inspectorate Yogyakarta, ejournal.uajy.ac.id/4867. Setiawan Slamet, 2012. Effect of Work Experience, Independence, And Competence Auditor on the Quality Audit by the Public Accounting In Surabaya.Jurnal Widya Mandala Catholic University SurabyaIndonesia.

Zhang Yang, Jian Zhou, and N. Z. (2007). Audit Committee Quality, Auditor Independence, And Internal Control Weaknesses. Journal of Accounting and Public Policy, 26, 300-327. 